\title{
Darwin and the Doctors: Evolution, Diathesis, and Germs in 19th-Century Britain
}

\author{
By W.F.Bynum
}

\section{Introduction: Darwin and Medicine}

Charles Darwin, it might be said, had medicine in his blood. His grandfather and father were successful physicians, and he himself seemed at one time destined to follow in their footsteps. 'My father', wrote Darwin, "who was by far the best judge of character whom I ever knew, declared that I should make a successful physician,-meaning by this one who would get many patients. He maintained that the chief element of success was exciting confidence; but what he saw in me which convinced him that I should create confidence I know not'. ${ }^{1}$ Dr Darwin's judgement was never put to the professional test, for Charles disliked his medical studies in Edinburgh and had to leave the operating theatre before the two operations he ventured to witness could be completed. Medicine's loss was science's gain.

Darwin abandoned his medical career without reluctance or regrets and, despite the subsequent award of the Baly Medal by the Royal College of Physicians, honorary medical degrees from three Continental universities, and honorary membership in the Medico-Chirurgical and the Physiological Societies, it can hardly be said that he maintained more than an ordinary interest in the vast changes in medical science or medical practice which occurred during his lifetime. His friends and correspondents included, of course, many doctors, such as Henry Holland, John Scott Burdon-Sanderson, his personal physicians Henry Bence-Jones and Andrew Clark, the pharmacologist Thomas Lauder Brunton, and the surgeons William Bowman and James Paget, at whose house Darwin was briefly in 1881 to meet Louis Pasteur. ${ }^{2}$ Despite Darwin's early squeamishness at the sight of human suffering, he valued medical research and was a firm friend of the physiologists in the $1870 \mathrm{~s}$ when antivivisection groups were agitating for controls which would have stymied a vigorous young experimental discipline then emerging in Britain ${ }^{3}$.

But the impact of medical theories or medical practice - in their narrow sense on Darwin's most creative work was relatively slight, with three 
exceptions. The first was Darwin's father. Darwin's early notebooks are filled with gems mined from Dr Darwin's medical practice: observations about human behaviour under conditions of pain and stress; about the impact of disease on mental functioning; about the importance of heredity in human beings. 'My father says' is a common opening for the thoughts and observations which Darwin privately committed to paper from 1837, when he was working out his evolutionary theories. Darwin absorbed from his father the medical materialism which any doctor who spends a lifetime caring for the sick and dying is almost bound to espouse, whatever his religious beliefs: the observation that the mind cannot work properly if the mind's machinery is disordered. We can, of course, never know when or why the young Darwin first decided that the mind was utterly dependent on the body. Five years of frequent seasickness on H.M.S. Beagle might have prodded him in this direction. But certainly his father's medical observations played an important role in Darwin's notebooks on 'Man, Mind and Materialism', and the underlying message permeated his life's work, and many specific points resurfaced years later in his two books on man, The Descent of Man, and The Expression of the Emotions in Man and Animals ${ }^{4}$.

A second source of medical inspiration came from James CrichtonBrowne (1840-1938), Medical Superintendent of the West Riding Asylum, at Wakefield, Yorkshire, from 1866 to 1875 . During the $1860 \mathrm{~s}$, when Darwin was again gathering material on physiognomy and emotional expression, he and Crichton-Browne carried on a productive correspondence, with the latter supplying Darwin with a large number of photographs depicting varieties of insanity, and discussing with him muscular physiology and the outward signs of disease ${ }^{5}$.

The other area of medical influence was related to a subject on which Darwin especially valued his father's observations: the problem of human heredity. He was always on the lookout for instances of inheritance in human beings, particularly examples of use and disuse inheritance and of habit, and like many high Victorians, he was acutely alive to familial patterns of disease. It is this latter-hereditary disease - which provided the only extended discussion of man in his two-volumed work on heredity, The Variation of Animals and Plants under Domestication. These instances were combed from older medical writers like John Hunter and Anthony Carlisle, from more recent medical works like Prosper Lucas' Traité de l'hérédité naturelle (1847-50), and from Darwin's medical friends like Henry Holland and William Bowman ${ }^{6}$. Darwin shared with others of his social class and 
station a sense of family history; like Tennyson, Gladstone and Thackeray, he had a heightened awareness of what he had received from his ancestors and passed on to his offspring ${ }^{7}$. His cousin Francis Galton, the childless father of eugenics, went even further, of course, in the systematic study of familial inheritance patterns ${ }^{8}$. But Darwin had already independently and earlier come to see the significance of transmitted variations for his own view of nature, and for this the concept of inherited disease and disease tendencies or diatheses were important. As we shall see, Darwin's work on variation subsequently reinforced medical perceptions of inheritance and seemed to give new biological significance to the notion of diathesis.

There were, of course, other medical sources for Darwin: embryology and comparative anatomy, for instance, or the writings of his own grandfather Erasmus ${ }^{9}$. But Darwin never really approached medicine as other than another body of observations and facts of potential use for his own more general biological theories. Human biology rather than medicine per se intrigued him, and we search his publications and private correspondence in vain for any extended comment on such matters as anaesthesia, public health, cellular pathology or antiseptic surgery, all of course important developments of Darwin's adult life.

\section{The Doctors and Darwin}

But what of the reverse? What have the doctors got from Darwin? The short answer is, that, like so many life scientists of the past century, a great deal. A series of monographs, ranging from K. W. Millican's Evolution of Morbid Germs (1883), through James Bland-Sutton's Evolution and Disease (1890), J.G. Adami's Medical Contributions to the Study of Evolution (1918), and Morley Roberts' Malignancy and Evolution (1926) to the recent book of R. M. J. Harper, Evolutionary Origins of Disease (1975), attest to the continuing preoccupation of a few doctors with the evolutionary perspective in understanding the biological and social significance of human disease.

These and similar works have escaped systematic historical examination, primarily because evolutionary thought has had a rather disparate impact on the theory and practice of medicine. The most striking instance is that of John Hughlings Jackson (1835-1911), whose fundamental contributions to clinical neurology were explicitly related to his concept of the evolution of higher and lower functions of the nervous system. Herbert Spencer 
(1820-1903) rather than Darwin was the immediate influence on Jackson, but his neurological framework is incomprehensible without reference to evolutionary ideas ${ }^{10}$. In addition, however, a whole range of medical scientists and clinicians, including W.H.Gaskell, Elie Metchnikoff, and Otto Warburg, have derived much from Darwin's work, and a number of medical problems, including the prevalence of sickle-cell anaemia among people of West African descent and the emergence of penicillin-resistant strains of bacteria, can be understood best through reference to Darwin's concept of natural selection ${ }^{11}$. Problems of immunity and changing microbial virulence are also part of the historical ecology of disease for which an evolutionary perspective has occasionally been fruitfully employed ${ }^{12}$. Finally, a number of metabolic disorders such as diabetes and gout have been placed within an evolutionary framework ${ }^{13}$.

These brief examples suggest a continuing relevance of Darwin's work for historical epidemiology as well as the study of present diseases and their mechanisms. Many of the more recent attempts to apply evolutionary thinking to disease have analogues in nineteenth-century medical responses to Darwin. I should like now to turn to two of these areas: the problem of heredity - the diseases of evolution - and the early reception of germ theory in Britain - the evolution of disease. In both areas, I would argue, Darwin's work casts some light on old problems rather than offering any radical new departure.

We have already noted that Darwin was particularly interested in instances of inherited disease or disease tendency, as part of his larger insistence that inherited variation must occur if natural selection was to have the effects which he claimed for it. Whereas his most telling examples came from the vast changes produced by selective breeding of domestic animals and plants, observations relating to familial patterns of disease were also explicable within the same broad framework. Now, the concept of diathesis has a long and venerable medical history ${ }^{14}$. It was a useful but extremely elastic and ultimately unfalsifiable idea, not unlike the neoGalenic notion of the faculty so elegantly satirized by Molière. For a diathesis was simply a constitutional tendency towards a disease. If a patient developed the disease for which he had the diathesis, the point was proved. If he did not, through careful living, premature death or fortuitous circumstance, this did not prove that he was lacking the diathesis, but merely that it had not expressed itself. A number of diseases were commonly assumed to be diathetic: consumption or tuberculosis, gout, hysteria and epilepsy are 
examples. Diathetic diseases had often been remarked to be on the increase, as a consequence of what the eighteenth century called luxury, and the nineteenth century called civilization. The price of progress, it seemed, was an increase in hysteria, hypochondria, nervousness and debility, all of which were expressions of diathetic abnormalities. Long before Darwin, a racial typology of disease had been worked out which posited that primitive peoples and the industrial poor succumbed to acute epidemic diseases while the civilized elites lingered with their chronic diathetic disorders. Darwin espoused roughly this typology in his Descent of Man, but this paradox of progress worried various doctors who ventured to suggest that natural selection did not fully operate in the case of man. The Birmingham surgeon and gynaecologist Lawson Tait (1845-1899) saw in 1869 the deteriorating constitutions of modern man as proof that medicine was keeping alive many who would otherwise have perished. Tait had scant regard for Herbert Spencer, with his built-in metaphysic of progress; rather he believed that the conditions of modern life inevitably permitted the survival and reproduction of individuals with physical and mental impairments which, in earlier, harsher environments, would have proved rapidly fatal. Tait's article, published in an 1869 issue of the Dublin Quarterly Journal of Medical Science, offered no practical solutions to the issue it raised, although perceptions like his were subsequently to fuel eugenic campaigns ${ }^{15}$. And by the 1870 s, hereditarian as opposed to environmental modes of analysis were more common among British doctors, as they among others began to feel the relative decline of British fortunes in international industrial competition, and to see the earlier optimistic environmentalism of public health reform fail to make significant inroads on the appalling mortality in the cities. We can see these strands in the increasing use made of the concept of hereditary degeneration in the psychiatric literature; in the medical temperance movement with its associated concern with inebriate asylums and legislation aimed at reducing the prevalence of the alcoholic diathesis; in Benjamin Ward Richardson's Diseases of Modern Life of 1875, with its analysis of what he called the natural life cycle and the ways in which this cycle was cut short by the excesses and temptations of modern life; and in works by two surgeons who were particularly close to Darwin: Sir James Paget (1814-1890) and Sir Jonathan Hutchinson (1828-1913).

Paget's 1882 Bradshaw Lecture On Some Rare and New Diseases relied on his own experience as Curator of the Hunterian Collection and his knowledge of the clinical literature to stress that diseases (like species) can and do 
appear and disappear over time. His primary example was the disease which he himself first described-osteitis deformans, now known as Paget's disease but he also suggested that various of the neuro-muscular disorders described by Charcot, Duchenne and others were also new. Paget recognized that he could never prove his case, but these diseases had such obvious clinical and pathological manifestations that Paget was convinced that their absence from earlier clinical literature and from material in pathological collections strongly suggested that they were new. These new diseases, and others previously rare but more commonly seen in the 1880 s, were, Paget suggested, "due mainly to morbid conditons changing and combining in transmission from parents to offspring'. They were diathetic conditions, and they were to be studied, he continued, "as Darwin studied the variations of species'. 16

This combination of reverence for Darwin's powers of observation and emphasis on diathesis was continued in Jonathan Hutchinson's lectures on The Pedigree of Disease, also delivered at the Royal College of Surgeons. Hutchinson, a Quaker Yorkshireman, was an extremely gifted clinical observer who left a number of eponyms, most famously Hutchinson's triad, the stigmata of congenital syphilis. Unlike Darwin, however, he was not a particularly distinguished theoretician. In The Pedigree of Disease, he distinguished between temperament, idiosyncracy and diathesis, stressing the importance of the latter in understanding not only the traditional diathetic disorders like gout, but a number of others such as malaria, leprosy and syphilis. Diseases, he insisted, echoing Darwin, should be placed 'in natural groups, in connection with their ancestral descent'. ${ }^{17}$

Two aspects of Hutchinson's concept of the diathesis merit comment. First, even though he defined it as a proclivity to definite forms of disease, the relation between environment and heredity was far from precise. Hutchinson and most of his medical colleagues in the 1880s still assumed that acquired characteristics could be inherited, so even the diathesis itself could be weeded out through the willed determination of the patient or could be acquired during one's lifetime. Through heredity nothing is lost, wrote Hutchinson, but because of this interplay of nature and nurture, social meliorism was possible. The diathesis could be looked upon as a kind of soil in which particular diseases grew with greater or lesser regularity.

Second, some of the particular diathetic conditions Hutchinson described remind us that, for many of them, such as malaria, syphilis and leprosy, an alternative aetiological framework was already potentially 
available by 1884. I mean, of course, the germ theory of disease ${ }^{18}$. Hutchinson's book was published two years after Koch had demonstrated the presence of the tubercle bacillus in cases of tuberculosis. Hutchinson never really came to grips with the nuances of the theory; but in the late $1870 \mathrm{~s}$ and 1880 s a number of doctors in Britain were closely following the results of what was still largely a Continental science. Several of them attempted to use a combination of Darwinian evolution and germ theory to explain a perennial medical problem: that of the specificity of disease. I should like to look briefly at the early reception of germ theory in Britain.

Now, the main outlines of the history of the germ theory are well known. They go like this. Earlier environmental, miasmatic ideas emphasized a general similarity between all the 'filth diseases', such as typhus, typhoid, infantile diarrhoea, cholera and relapsing fever. By identifying the causation of these epidemic diseases as atmospheric, early Victorian public health advocates were reluctant to posit too much specificity among these filth diseases. Rather, they attributed them all to the same insanitary cluster of causes: bad housing, impure water, putrefying flesh, bad drainage, dirt, etc. ${ }^{19}$ But from the mid-nineteenth century, beginning with John Snow's brilliant epidemiological studies of the water-borne propagation of cholera, and continuing through the investigations of Pasteur, Koch and others, from the $1860 \mathrm{~s}$ the germ theory brought a new precision into medical thinking. It underlay a new nosology in which the germ and the disease were partially equated, and this new nosology could talk of disease specificity on the basis of this causative or aetiological agent. Because the germ is a species, the disease is specific.

Over the long haul, the story is roughly correct. But the early reception of germ theory in Britain suggests two substantial qualifications. In the first place, the notion of disease specificity was much more firmly entrenched in medical thought than is suggested if we concentrate on the Chadwickian public health literature alone. For a specificity based not on aetiology but on pathological anatomy underlay many of the achievements of the early nineteenth-century French school of Corvisart, Laennec and their colleagues, and was continued by the high priests of Victorian hospital medicine such as Robert Carswell, William Jenner and Thomas Hodgkin. The French clinician Armand Trousseau could insist in the 1850s that the notion of disease specificity was the foundation of all medicine ${ }^{20}$.

But specificity had its clinical as well as epidemiological difficulties, for many doctors had experience of cases of epidemic diseases seeming to change 
character in the middle of an epidemic, or a patient exposed to measles or diphtheria subsequently coming down with smallpox or typhoid. There was still in the $1860 \mathrm{~s}$ a body of opinion which saw all the fevers as essentially similar kinds of disease and therefore to be treated by the same general methods. John Harley $W$ arner has recently examined the fevers literature in Edinburgh in the 1850s, which debated whether fever had changed its character between the late eighteenth and early nineteenth centuries, when it was generally treated by depletive measures such as purging and bloodletting, and the mid-nineteenth century, when many physicians felt that bloodletting was precisely the wrong treatment in fevers. Warner has shown that apostles of the new scientific medicine like John Hughes Bennett were confident enough in their own professionalism to suggest that earlier doctors like William Cullen had simply been incorrect in their treatment of fever, rather than covering their forebears by insisting that bloodletting had been appropriate for eighteenth-century fevers because their character was different. Fever, Bennett said, had not changed ${ }^{21}$.

The second qualification of the above brief outline of the impact of germ theory is the idea that it reinforced the concept of disease specificity. In the late 1870s and early 1880s, germ theory did precisely the opposite. Early exponents of the germ theory in Britain like Sir William Aitken, Kenneth Millican, Sir William J. Collins, Thomas Maclagen, Sir William Roberts and William Pearse believed that the germ theory was compatible with cases of apparent cross-infection, and of changing character of germ diseases over time. They all invoked Darwinian evolution to justify their clinical and microscopic observations ${ }^{22}$.

Much confusion still surrounded the germ theory in 1880. Although most doctors accepted the frequent-and perhaps even universal-presence of micro-organisms in many diseases like anthrax and scarlet fever, it was not always clear whether they were cause or effect. For one thing, Henry Charlton Bastian (1837-1915) still believed in the abiogenesis, or spontaneous generation of micro-organisms. While most proponents of the germ theory accepted the experimental work of Pasteur in France and John Tyndall in England, showing that spontaneous generation does not occur under ordinary laboratory conditions, an alternative doctrine of heterogenesis still seemed possible to many microscopists. Whereas abiogenesis required the generation of life from non-living elements, heterogenesis necessitated merely the recombination of portions of the protoplasm of micro-organisms to yield a new form ${ }^{23}$. 
A further difficulty faced by doctors in the 1880s was deciding between the relative importance of the intact micro-organism and its breakdown products in causing the symptoms of disease. For if, as some evidence suggested, the actual damage was chemically rather than cellularly caused, the precise relationship between the specific organism and a specific disease seemed less clear.

It was these and similar problems which Millican, Aitken and the others faced. Aitken's is the widest-ranging account, and I shall confine my concluding remarks to his series of articles published in 1884 and 1885 in the Glasgow Medical Journal. Aitken, a Fellow of the Royal Society and Professor of Pathology at the Army Medical School, drew his inspiration primarily from Darwin rather than Spencer. Darwin's work, he insisted, made it imperative for the doctor to examine both the seeds of disease and the soil. Hereditary racial and personal features clearly affected the extent to which the seed might cause disease. But it was in the changing historical character of infectious diseases that Darwin's theory had most cogency. As Aitken pointed out, however, the doctrine of evolution was not a new one in medicine. In the late eighteenth century John Ferriar had discussed changes in form in diseases, and in the very year Darwin published the Origin, Charles Murchison described the co-existence of smallpox and measles, and smallpox and scarlatina. Throughout the $1860 \mathrm{~s}$ and $70 \mathrm{~s}$, various physicians continued to describe instances of diseases changing character, although their comments often failed to stress the evolutionary significance of the observations. Aitken added an evolutionary gloss to much of this earlier literature. Although a firm advocate of germ theory, he admitted that for most of the infectious diseases he discussed, no clear organism had been identified. Further, he leaned towards the chemical rather than the cellular source of many of these diseases, such as typhus, malaria and enteric fever. But it was clear to him that micro-organisms were implicated either directly or indirectly.

Aitken's primary conclusions were two. First, the fundamental law of life was incessant variability, in both men and micro-organisms. The primary task of medicine and pathology was to understand this process, and to relate it to racial and individual aspects of disease. The second conclusion followed: because of variation, the notion of clinical specificity was only partially true. Diseases could change, and it thus behoved the doctor to observe historically: to follow generations of bacteria or fungi, looking for modifications in their characteristies, and to analyse individual patients in terms of their family and racial histories ${ }^{24}$. 
In the long run Aitken's insistence on the dynamic and highly variable character of infectious diseases was of limited use, although the example of penicillin-resistant bacteria reminds us how rapidly microbes can significantly change. And Darwin himself did not live to comment on Aitken's attempt to apply his evolutionary perspective to medicine. Darwin did however live to see the beginnings of the germ theory, and he welcomed it. As he wrote to Ferdinand Cohn, in 1877, replying to a letter from Robert Koch's mentor which had described the latter's researches on splenic fever,

'I well remember saying to myself, between twenty and thirty years ago, that if ever the origin of any infectious disease could be proved, it would be the greatest triumph to science; and now I rejoice to have seen the triumph.'25

It is probably true, as Dr Harper has recently insisted, that medicine has remained largely aloof from evolutionary theory ${ }^{26}$. But there is good evidence that during Darwin's later years and shortly after his death, not a few British doctors recognized Darwin's remarkable observational powers, sought to emulate them, and attempted-with varying success - to apply his ideas to their professional concerns.

\section{Footnotes}

${ }^{1}$ Francis Darwin, ed., The Life and Letters of Charles Darwin, 3 vols. (London, John Murray, 1888), I, p.37.

2 In addition to n. 1.. see Francis Darwin, ed.. More Letlers of Charles Darwin, 2 vols. (London, John Murray, 1903); and Stephen Paget, ed.. Memoirs and Letters of Sir James Paget (London, Longmans, 1902), p.412.

${ }^{3}$ R. D. French, Antivivisection and Medical Science in Victorian Society (Princeton University Press, 1975).

4 H. E. Gruber, Darwin on Man (London, Wildwood House, 1974).

5Sander L. Gilman, Seeing the Insane (New York, John Wiley, 1982), Chapter 15.

${ }^{6}$ Charles Darwin, The Variation of Animals and Plants under Domestication, 2 vols. (London, John Murray, 1868), II, Chapter 12.

7 Eg., Robert B. Martin, Tennyson: The Unquiet Heart (Oxford, Clarendon Press, 1980).

${ }^{8}$ D. W. Forrest, Francis Galton: the Life and Work of a Victorian Genius (Iondon, Paul Elek, $1974)$.

"Desmond King-Hele, Doctor of Revolution: the Life and Genius of Erasmus Daruin (London, Faber, 1977).

10 A. M. Lassek, The Unique Legacy of Doctor Hughlings Jackson (Springfield, III., C. C. Thomas, 1970).

11 There is a good deal of historical material on such issues in Sol Tax, ed., Evolution after Darwin, 3 vols. (Chicago, University of Chicago Press, 1960). 
12 Cf. T. A.Cockburn, "The origin of the Treponematoses", Bull. Wld. Hlth. Org. 24. (1961), 221-228.

${ }^{13}$ R.M. J. Harper, Evolutionary Origins of Disease (Barnstaple, G. Mosdell, 1975), Chapters 3 and 5 .

14 E. H. Ackerknecht, "Diathesis: the word and the concept in medical history", Bull. Hist. Med., 56 (1982), 317-325.

15 W. J.Stewart McKay, Lawson Tait, His Life and Work (London, Baillière, 1922).

${ }^{16}$ Sir James Paget, On Some Rare and New Diseases (London, Longmans, 1883), p. 21.

17 Jonathan Hutchinson, The Pedigree of Disease (London, Churchill, 1884), p. 133.

${ }^{18}$ O. Temkin, "The scientific approach to disease: specific entity and individual sickness", in The Double Face of Janus (Baltimore and London, Johns Hopkins University Press, 1977), pp. 441-455.

19 Margaret Pelling, Cholera, Fever and English Medicine, 1825-1865 (London, Oxford University Press, 1978); E.H.Ackerknecht, "Anticontagionism between 1821 and 1867", Bull. Hist. Med., 22 (1948), 562-593.

20 Trousseau is quoted by W.J.Collins (Lancet, 1881, i, p.812) as having remarked of the doctrine of disease specificity: «Elle domine toute la pathologie, toute la thérapeutique; en un mot, toute la médecine».

21 J.H. Warner, "Therapeutic explanation and the Edinburgh bloodletting controversy; two perspectives on the medical meaning of science in the mid-nineteenth century", Med. Hist. $24(1980), 241-258$.

${ }^{22}$ Some samples of this literature include K. W. Millican, The Evolution of Morbid Germs (London, H. K. Lewis, 1893), T. J. Maclagan, Fever, A Clinical Study (London, Churchill, 1888).

${ }^{23}$ John Farley, The Spontaneous Generation Controversy from Descartes to Oparin (Baltimore and London, Johns Hopkins University Press, 1977).

${ }^{24}$ William Aitken, "Darwin's doctrine of evolution in explanation of the coming into being of some diseases", Glasgow Med. J. 24 (1885), 98-107, 160-172, etc.

${ }^{25}$ Darwin (n. 1). III, p. 234.

${ }^{26}$ Harper (n. 13).

\section{Zusammenfassung}

Zuerst wird dargestellt, was Darwin von der Medizin und den Medizinern seiner Zeit gelernt hat; Vater und Großvater waren Ärzte, er war mit vielen Ärzten befreundet. Dann wird untersucht, welchen Einfluß die Schriften von Darwin auf medizinische Autoren Englands ausgeübt haben. Die Evolutions- und Selektionstheorien beeinflußten die Lehre von den Erbkrankheiten, den Diathesen, wie man sie damals nannte. Wichtig waren sie auch für die Theorie der Krankheitserreger. Es ging darum, die pathogenen Keime als eigentliche Spezies anzuerkennen, deren Spezifität je eine spezifische Krankheit bedingt. In die neuste Zeit führten die Erkenntnisse über Veränderungen von Erregern nach den Gesetzen der Selektion, wie z.B. die Entstehung von gegen Penicillin resistenten Bakterienstämmen.

Dr. W.F.Bynum

Wellcome Institute for the History of Medicine, 183 Euston Road, London NW1 2BP, England 